\title{
MARTYRDOM AND THE PROCESS OF RADICALISATION AMONG YOUNG MUSLIMS IN INDONESIA: SOCIAL IDENTITY THEORY PERSPECTIVE
}

\author{
Muhammad Syafiq \\ Program Studi Psikologi Universitas Negeri Surabaya \\ e-mail:syafiq_muh@yahoo.com
}

\begin{abstract}
The phenomena of suicide attacks targeting overseas people or properties in Indonesia carried out by Indonesian young Muslim seem to be elusive. Different to Palestinian and Middle Eastern contexts where acute conflicts are taking place, there were no celebrations to martyrdom in Indonesia. Majority of Indonesian Muslims not only reject suicide bombing or martyrdom but also condemn it. Indonesian suicide bombers' families, that is not like those of Palestinian martyrs, were not proud of their member's deed and will not get pride from their neighbourhood. They will not get financial advantages because offamily's member sacrifice as well. So, what are the reasons that make Indonesian young Muslims chose to die as a martyr? This article aims to explain the process of radicalisation among young Muslims and reveals the causes and backgrounds of young martyrs in Indonesia based on Social Identity Theory (SIT). Findings of many studies on religious motivated violent attacks are used as comparisons.
\end{abstract}

Keywords : Terrorism, youth, radicalisation, martyrdom.

In the early morning of July $17^{\text {th }} 2009$, two separated blasts hit Ritz-Carlton and J.W. Marriott Hotels, Jakarta. Indonesian police then announced that the blasts were suicide bombings of two terrorists named Nana Ikhwan Maulana (28 years) and Dani Dwi Permana (19 years). Seven people were killed and more than 50 others were injured in these attacks. Formerly, two Bali bombings occurred on October 2002 and October 2005 and killed more than 200 people. The profiles of both perpetrators of terrorist attacks on Ritz-Carlton and J.W. Marriott Hotels, according to Davis (2010), corroborates a historical profile for radical Muslim extremists in Indonesia. He stated that most actors of terrorists attacks in Indonesia are young, male, single, and little or no education.

Studies on terrorist profiles has been carried out by many social scientists including psychologists. Horgan (2003) reviewed many psychological literatures on terrorism in the periods of 1970s-1980s and found that it was common in the earliest psychological studies that terrorists are viewed as people who suffer from mental disorder, frustration, or narcissism.

However, recent studies show that terrorists have normal psychological characteristics. Based on many literatures and research findings on Palestinian suicide bombers, Silke (2003:94) concluded that 'there is no indication that suicide bombers suffer from psychological disorder or are mentally unbalanced.. In contrast, their personalities are usually quite stable and unremarkable (at least within their own cultural context)'.

Based on videos revealing confessions of three perpetrators of second Bali Bombings on October $1^{\text {st }} 2005$, Indonesian psychologist, Sarlito Wirawan Sarwono, concluded that they cannot be categorized as psychopaths. Sarwono (2007:3) said: 'they love, are devoted and are responsible to their families, they expressed normal emotion, they are able to show empathy, they behave politely, they avoid rude vocabulary in their speech, and ...have never committed a crime.' He stated that rather than become the real actors of terrorism, Indonesian suicide bombers are the victims of indoctrination. He stated that candidates of suicide bombers generally are recruited among young people who are ambivalent, disoriented and socialpsychologically isolated or, in his terms, are 
'empty mind' (Sarwono, 2007: 3). The suicide bomber candidates viewed as the ones who have no intellectual ability to counter the recruiters' radical Islamic ideology.

However, Silke (2003) rejects the idea of brainwashing or indoctrination as the main factors of individual's decision to be a martyr. He noted that in the context of Palestine, most suicide bombers are volunteers who chose consciously to be a martyr although other alternatives remained open to them.

The idea of indoctrination as the cause of the youth's involvement in terrorism is apparently rooted in Erickson's concept of identity crises. According to the perspective, we can assume that young suicide bombers were easy to be recruited because they were suffering from ambiguity, fragmentation, and isolation. Young people that suffer from such crises tend to seek totalitarian collective identities that promise certainty, and radical terrorist group is one of the choice.

However, if the collective cultural background of Indonesian people is taken into consideration, it will be important to scrutinize whether young Indonesian Muslims who are living in collective Indonesian culture have periods of identity crises?

\section{Local Culture as a Determinant Factor}

Reflecting on Palestinian suicide bombers, Grosbard (2008) argued that in traditional-collectivistic cultures, parents have important roles to make decision on their children. This tends to make adolescent periods in traditional collective society remains peaceful. Then, in this collective traditional society, Grosbard (2008: 147) said: 'there is no individual identity search, and usually rebellion which defines the self is out of the question'.

Individuals who live in collective society usually have a more dominant external locus of control than internal ones. Their motivation and behaviour then will be influenced more by situational factors rather than by their internal factors. Therefore, the ways Indonesian suicide bombers were recruited will elicit a valuable information about their motivation.

In the case of 17 July bombings, police investigators revealed Syaifudin Zuhri as the man who recruited Dani and Nana. According to Osman (2009), Syaifudin searched his targets in Mosques that are visited by many university students and he would take a time to engage with them intellectually. Syaifudin's target, then, basically is a curious, intelligent young man. Therefore, the candidates of Indonesian suicide bombers less likely have 'empty mind' or be brainwashed or indoctrinated by terrorist groups. They chose to be a martyr based on self awareness as showed in the video recording of Dani's confession: 'it will scare them, America and Australia will be destroyed, so this is not suicide'(Aljazeera TV programme "witness", 2010).

If it is true that the candidate of suicide bombers choose to be a martyr voluntarily and consciously, so what is social psychological mechanism behind their decisions? In fact, not all members of radical group choose to die as martyr, so the path from joining radical groups to martyrdom is not a simple transformation. Social identity theory (SIT) will be an appropriate tool to explain how Indonesian young Muslims join radical groups and choose to die as a suicide bomber.

\section{The Construction of a Radical Group's Collective Identity}

Social identity theory (SIT), according to Hogg \& Abrams (2003), asserted that we will define and evaluate ourselves based on groups to which we belong. SIT addressed how groups membership leads to the formation of social identities together with its emotional and value significance. According to SIT, Individuals are motivated to identify themselves with their groups and seek positive self-esteem and self enhancement by 
distinguishing their ingroup from outgroup.

Social Identity Theory (SIT) consists of Tajfel's original social identity theory and Turner's social categorisation theory. The former explain how groups membership leads to the formation of social identities together with its emotional and value significance, the latter examine ways in which social identities operate as social categories in self concept in the context of intergroup dynamics including stereotype and prejudice (Herriot, 2007).

Herriot (2007) has applied SIT to study religious fundamentalism specifically focus on the cases of 9/11 hijackers and Anglican Church. According to Herriot, religious identity seems to be prominent in religious fundamentalism both in Islam and Anglican Church. In those cases, religious identity was constructed around the sacred worldview so that if the believers sense their identity is threatened in the context of intergroup conflicts, their reactions that are often violent will be sacralised in religious terms. In fact, religion has the power to morally justify any actions and promises an eternal reward in heaven to the true believers (Kinvall, 2004).

Based on the arguments, we can argue that for some young Muslims, all Muslims in the worlds are in-group. Self identification to all Muslims around the world make youth's religious identity is more salient than their other identities. In this condition, young Muslims will be moved emotionally if there are conflicts in the Muslim areas which involved out-groups, especially in the condition Muslims are oppressed and suffering. They will feel grievance for Muslims and angry to enemies. In this conditions, radical groups find a fertile soil where they can deliver their messages and invite young Muslims who are eager to fight for changing their groups' conditions to support and even join into the group. Thus, the radicalisation of young Muslims is the process that created by radical groups by spreading radical ideology from which they can find supporters and, then, /select and recruit their members.

In the light of SIT, the first step to explain the process of radicalisation among Indonesian young Muslim is to reveal how they identify themselves into their groups and which out-groups they identify as competitors or enemies. Richardson (2006) stated that terrorist organization usually mobilizes a single shared identity to recruit their members. Post (2005) has also showed the importance of emphasising on collective identity as foundation of terrorist psychology. To answer how collective identity based on Islamic religion campaigned and mobilised by radical groups in Indonesia, we have to look at the recent condition of Indonesian Muslim society as general.

Being the highest Muslim population in the world, Indonesian Muslims, together with other Muslims in the Southeast Asia region, were previously described as having, in Mehden words, '..a greater reputation for pluralism, flexibility, and tolerance than that found in the Middle East' (Mehden, 2005:3).

However, compare to the earlier years, Indonesian Muslims today are more aware of what happening in Islamic world and tend to sense that Islam now is under attack of outside forces so that they are, Mehden said: 'more fully identify themselves with global Islamic community' (Mehden, 2005:3). This global Islamic community is best termed in Islamic perspective as 'ummah' which is means, according to Watt (1956: 242), 'the religious community of Muslims.' Normally, all Muslims in the world are parts of ummah that are bound by the same religion, however not all Muslims feel the same degree of sentiment and solidarity as one ummah .

In this situation, when devout young Muslims meet radical groups that tell them the groups are struggling to counter-attack the enemies to defend religious community or ummah, we can predict that they will attract to the groups. Roy (2004) stated that a radical Islamic group is so attractive because it claimed themselves as the vanguard of 
ummah. Although the role of ummah here is just as, in Roy terms: 'an imaginary and therefore silent community that gives legitimacy to the small group pretending to speak in its name' (Roy, 2004: 200).

\section{The Process of Radicalisation}

Radicalisation defined by McCauley \& Moskalenko (2008:416) as : 'change in beliefs, feelings, and behaviours in directions that increasingly justify intergroup violence and demand sacrifice in defense of the in-group.' The function of radicalisation, according to them, is to intensify readiness and commitment to intergroup conflicts. In the context of terrorism in Indonesia, radicalisation is closely related to armed struggles in the contexts of real or imagined intergroup conflicts between Muslim and its enemies.

The process of radicalisation can be more understood clearly when we consider "the staircase to terrorism" explained by Moghaddam (2005). According to Moghaddam, becoming a terrorist is not an automatic process. It needs many steps that require terrorist candidates to climb gradually through some stairs.

Moghaddam (2005) stated that there are at least six levels or "floors" leading to terrorist acts. In the lower level or ground floor, there are perceptions and feelings of injustice and deprivation among people. Then, some individuals who think and feel that they should try to get solution will climb to the higher level (first floor). In this level, they do some efforts to seek the ways to make their situation better and claim their justice. The failure to succeed in the first level will make individuals keep climbing to second level.

In the second level, individuals bring the feeling of anger, hate, and frustration with them and are vulnerable to be influenced by some leaders to displace the negative feelings onto common enemy. Some individuals who are prone to act aggressively to "the enemy" as a displacement of their anger and frustration will move higher to third level.

In the third level, the belief that physical violence can be use to punish "the enemy" and achieve their goals become more stronger. Because of the belief in the violent strategy, in this level individuals experience, According to Moghaddam (2005), the most important transformation, namely they begin to engage with the morality of terrorist organisations and justify violent offences as legitimate strategy. Some individuals in the third level, then, become more fully engaged with the terrorist morality and are ready for recruitment.

The fourth level is occupied by individuals who have already recruited as an active terrorist. They have been radicalised so that they see their terrorist organisation as legitimate and categorised the world rigidly into "us-and them", "black and white".

In the last level, specific members among the active terrorists are selected and trained to become "the chosen ones" who are ready to killing both others and themselves. Martyrs or suicide bombers, according to Moghaddam, are in this highest level.

\section{The Path to Martyrdom}

As stated by Moghaddam (2005), individuals who are equipped and sent to undertake terrorist acts and are ready to kill others and even themselves are selected and trained active terrorists. Young people are prone to influenced by leaders to do physical violent acts to attack common enemy. Joining radical groups that proclaim they have legitimacy from ummah to fight against enemies, make young Muslims feel themselves as a chosen person to perform religious duty. In this step, the role of small underground terrorist group is very essential to urge its members to take extreme actions.

The perception of being threatened by others will make members of radical groups very cohesive, and this cohesiveness will be more intensive when the group is smaller. In this condition, Mccauley \& Moskalenko said: 
'the group's consensus about value and morality acquires enormous power, including the power to justify and even require violence against those who threaten the group' (Mccauley \& Moskalenko, 2008: 423).

In this high cohesive small group, a personal interest of its member will be less important compare to collective group interests. All members will act and behave based on in-group norms and even be ready to sacrifice themselves for the group and ideology. In this level, the group ideology will gain its most powerful influence.

The radical Islamic organisation in Southeast Asia named Jemaah Islamiyah (JI) was responsible for most terrorist attacks in Indonesia (Abuza, 2009). JI has affiliation to Al-Qaeda and shares the same ideology called Salafi-Jihadism (Abuza, 2009). International Crisis Group (2004: 32) define Salafi Jihadism as 'a fringe element of salafism determined to target Islam's enemies through violence, aimed in particular at United States and its allies'.

The followers of this ideology differs from mainstream salafi Muslims in that they believe violent jihad is a legitimate way to fight their perceived enemies (Hooker and Fealy, 2006: 5). Globalisation enables the spread of this ideology to various parts of the world, including Indonesia, by facilitating the development of a religious identity based on a 'global ummah' united by awareness and concern for the perceived injustice and oppression of Muslims (Roy, 2004; Staunton, 2008). The 'Salafi Jihadi organisations act on these feelings of injustice by choosing to commit terrorism against perceived oppressors.' (Staunton, 2008:145).

According to Moghadam (2008) Salafi Jihadi admire martyrdom as a an manifestation of supreme devotion to God. The confession from one of terrorists involved in 2003 J.W. Marriott bombing in Jakarta supports this argument:

'Based on the fatwa [of Osama bin Laden urging attacks on the US and its allies], we wanted to defend the Muslim faithful who were being oppressed by the people of the US, England, Australia and Israel, by undertaking acts of terror aimed at facilities owned by Americans, British, Australians or Israelis in the hope that these acts would cause loss of life and property and strike fear into the hearts of the people of those countries.' (ICG, Asia Briefing $\mathrm{N}^{\circ} 94 ., 2009: 4$ )

It is not surprising, then, if some young extrimist Muslims, as members of terrorist groups, also admire martyrdom as their ideals because martyrdom is their highest group norm. However, making decision to be a martyr is different to committing martyrdom. It needs strong mentality and perseverance for a young man to blow himself without fear. Pedahzur (2005) said that terrorist groups use two effective mechanisms to solve this issue. Firstly, if the candidates have decide to be a martyr, the recruiters will make a short video of a candidates' last statement prior to their mission. After this video shooting, the candidates will be praised by their comrades as a living martyr or 'a bride'. Secondly, the recruiters will guide the candidates personally to carry out intensive religious rituals to prepare them enter to a heaven. Both mechanisms become the guarantee that the "brides" will not set back from their mission.

\section{CONCLUSION}

Terrorism in Indonesia is a part of global terrorism. Therefore, Indonesian suicide bombers' motivation generally is sourced from global Muslim community issues. Indonesian young Muslims sense themselves as a part of global religious Muslim community. As they perceive their Muslims community are invaded by outsider forces, they are eager to participate and give contribution to defend their radical in-group's interests which are certainly claimed by the radical group as the interests of ummah. This sentiments of Indonesian young Muslims to global Muslim 
community or ummah make them attracted to radical groups. To recruit them, a terrorist group try to raise their spirits, strengthen their motivation to fight for Islam, give religious justification, and then train the candidates the ways to undertake terrorist acts .

The process of transformation from young radicals into the candidates of martyrs is primarily depend on small radical terrorist group processes. The structure of the groups and dynamic interaction between its members determine the roles each members have to play. Candidates of the martyrs must be the most loyalist members who are ready to sacrifice their lives on behalf of group ideology. The ideology of Indonesian terrorist groups is sourced from Salafi Jihadism that praises martyrdom as an effective strategy.

\section{DAFTAR PUSTAKA}

Abuza, Zachary (2009). The Rehabilitation of Jemaah Islamiyah Detainees in South East Asia: A Preliminary Assessment. In T. Bjorgo and J. Horgan (Eds.). Leaving Terrorism Behind: Individual and Collective Disengagement. New York: Routledge.pp. 193-211

Aljazeera. (2010). TV programme "witness". http://english.aljazeera.net/ programmes/witness/2010/08/2010816 64431710754.html.

Davis, Drew, (2010). Al-Qaeda in the Malay Archipelago: A Case Study of the July 2009 JW Marriott \& Ritz-Carlton

Bombings in Jakarta, Indonesia. http://www.paxamerica.org/wpcontent/uploads/2010/03/CASESTUDY-The-July-2009-JW-MarriotRitz-Carlton-Bombings-in-Jakarta.pdf

Grosbard, Ofer (2008) The Drama of the Suicide Terrorist, in M. Sharpe (Ed.), Suicide Bombers: Psychological, religious and Other Imperatives. Amsterdam: IOS Press. p.145-150.

Hogg, M. A. \& Abrams. D. (2003). Intergroup Behavior and Social Identity, in M. A. Hogg \& J. Cooper (eds.). Handbook of Social Psychology. (pp. ). London: Sage.

Hooker, V. and Fealy, G. (2006). Introduction to the Sourcebook, in V. Hooker, and G.. Fealy, (Eds.). Voices of Islam In Southeast Asia: A contemporary Source
Book. Singapore: Institute of Southeast Asian Studies.

Horgan, John (2003) The search for the Terrorist Personality, in Andrew Silke, (ed.) Terrorists, Victims, and Society: Psychological Perspectives on Terrorism and its Consequences. West Sussex: Jon Wiley \& Sons Ltd., pp.5-16. Horgan, John (2008). Deradicalisation or disengagement?. Perspectives on Terrorism, 2(4): 3-8. Available at: http://www.terrorismanalysts.com/pt/a rticles/issues/PTv2i4.pdf

International Crises Group (ICG) (2004) Indonesia Backgrounder: Why Salafism and Terrorism Mostly Don't Mix. Asia Report No. 83. Brussels: International Crisis Groups. http://www.seasite.niu. edu/Indonesian/Islam/83 indonesia backgrounder_why_saläfism_and_ terrorism_don_t_mix_web.pdf

International Crises Group (ICG) (2009, 24 July). Indonesia: The Hotel Bombings. Asia Briefing $\mathrm{N}^{\circ} 94$. Jakarta/Brussel. http://www.crisisgroup.org/en/regions/ asia/south-east-asia/indonesia/B94indonesia-the-hotel-bombings.aspx

Kinnvall, Catarina (2004). Globalization and Religious Nationalism: Self, Identity, and the Search for Ontological Security. Political Psychology, 25(5):741-767.

McCauley, C. \& Moskalenko, S. (2008). Mechanisms of Political Radicalisation: 
Pathways Toward Terrorism, Terrorism and Political Violence, 20:415-433.

Mehden Fred, R. Van Der. (2005). Radical Islam in Southeast Asia and its Challenge to U.S. Policy. James Baker III Institute for Public Policy of Rice University.

Moghadam, Assaf. (2008). The Globalization of Martyrdom: Al-Qaeda, Salafi Jihad, and the Diffusion of Suicide Attacks. Maryland: The John Hopkins University Press.

Moghaddam, Fathali. M. (2005). The Staircase to Terrorism: A Psychological Exploration. American Psychologist, 60 (2), 161-169.

Osman, Sulastri. (2009). The Fatal Allure of Extremist Logic: Syaifudin Zuhri and the July 17 Suicide Bombers, RSIS Commentaries, Nanyang Technology University Singapore. Available at: http://www.rsis.edu.sg/publications/Pe rspective/RSIS1042009.pdf

Pedahzur, Ami (2005). Suicide Terrorism. Cambridge and MA: Polity.

Post, Jerrold M. (2005). The Psychological and Behavioral Bases of Terrorism: Individual, Group and Collective Contributions. International Affairs Review, 14 (2), 195-204. http://www.
iar-gwu.org/files/2005/FW05 Spotlight.pdf

Richardson, L. (2006). What terrorist want. Understanding the terrorist threat. London: John Murray.

Roy, Oliver. (2004). Globalised Islam: The Search for a New Ummah. London: Hurst \& Co. (publishers) Ltd., p.200.

Sarwono, Sarlito W. (2007). What is in their minds?: The psychology of suicide $b o m b e r s \quad i n$ Indonesia.http://www.victoria.ac.nz/nz iia/assets/talks/wn/What $\% 20$ is $\% 20 \mathrm{in} \%$ 20ther\%20Minds\%208\%20November 2007.pdf

Silke, Andrew (2003) The Psychology of Suicidal Terrorism, in Andrew Silke (ed.). Terrorists, Victims, and Society: Psychological Perspectives on Terrorism and its Consequences. (pp.94- ). West Sussex: Jon Wiley \& Sons Ltd.

Staunton, Dick (2008). The Clash of Identities: An Analysis of The Causes of Salafi Jihadi Terrorism with Reference to Jemaah Islamiyah, Studies in Ethnicity and Nationalism, 8(1): 142164.

Watt. Montgomery. (1956). Muhammad at Medina. Oxford: Clarendon. 